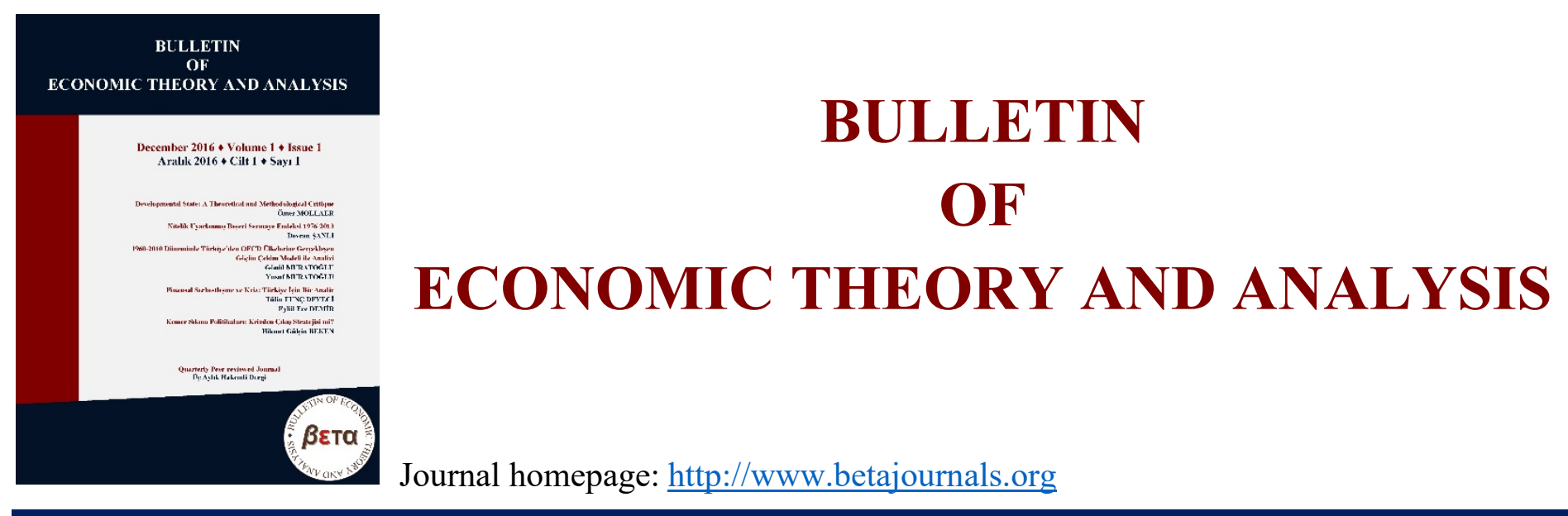

\title{
Türkiye'deki Sağlık Harcamalarının Sosyal Tüketim Harcaması Niteliği: Kuramsal Temelli Bir Değerlendirme
}

\section{Esra DOĞAN $\odot \underline{\text { https://orcid.org/0000-0002-9886-4186 }}$}

To cite this article: Doğan, E., (2021). Türkiye'deki Sağlık Harcamalarının Sosyal Tüketim Harcaması Niteliği: Kuramsal Temelli Bir Değerlendirme. Bulletin of Economic Theory and Analysis, 6(1), 27-51.

Received: 11 Dec 2020

Accepted: 11 Feb 2021

Published online: 30 Jun 2021

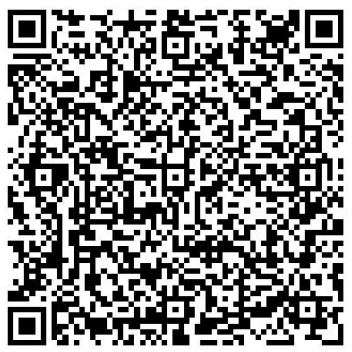




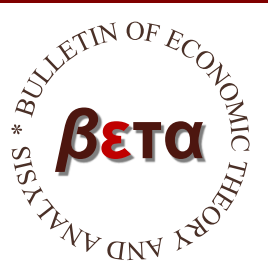

\title{
Bulletin of Economic Theory and Analysis
}

Volume VI, Issue 1, pp. 27-51, 2021

http://www.betajournals.org

Original Article / Araştırma Makalesi

Received / Alınma: 09.12.2020 Accepted / Kabul: 11.02.2021

\section{Türkiye'deki Sağlık Harcamalarının Sosyal Tüketim Harcaması Niteliği: Kuramsal Temelli Bir Değerlendirme}

\author{
Esra DOĞANa \\ a Arş.Gör.Dr. Eskişehir Osmangazi Üniversitesi, İIBF, Maliye Bölümü, Eskişehir, TÜRKIYYE \\ (1) https://orcid.org/0000-0002-9886-4186
}

\section{öz}

$\mathrm{Bu}$ çalışmanın amacı kamu harcaması niteliğindeki sağlık harcamalarının kapitalist üretim biçimi dahilindeki işlevini, James O'Connor'ın Devletin Mali Krizi adlı çalışmasından hareketle değerlendirmektir. Söz konusu çalışmada kapitalist üretim ilişkileri dahilinde devletin konumu incelenmekte ve buna bağlı olarak da devletin işlevlerinin devlet bütçesine yansıması ortaya koyulmaktadır. Devlet bütçesindeki bu yansıma devletin işlevleri bağlamında kamu harcama kalemlerinin kategorizasyonu ile açıklanmaktadır. O’Connor tarafından devlet bütçesi kapsamındaki kamu harcama kalemlerinin bütün olarak sinıflandırılması yapılmakla birlikte, yapılan bu sınıflandırmada harcama kalemleri alt düzeyleri itibariyle kesin bir ayrıma da tabi tutulmamaktadır. Ancak sağlık harcaması gibi birtakım harcama kalemlerinin kategorisine ilişkin de doğrudan ve dolaylı göndermeler bulunmaktadır. Bu çalışma kapsamında ise O'Connor'ın yaptığı bütçe kalemleri arasındaki kategorizasyonuna göre Türkiye'deki sağlık harcamalarının kategorisini belirleyebilmek amacıyla Türkiye'deki sağlık sisteminin genel yapısı ve bu yapı bağlamında genel bütçe kapsamındaki sağlık harcamalarının değerlendirmesi yapılmaktadır. Genel bütçe kapsamındaki sağlık harcamalarının ise merkezi yönetim bütçesi ve SGK bütçesi olmak üzere iki farklı yapı dahilinde bulunması, Türkiye'deki sağlık harcamalarının tek bir kategori altında sınıflandırılamamasına neden olmaktadır. Bu çalışma ile de genel bütçe kapsamındaki söz konusu ayrımın, sağlık harcamaları kapsamındaki önemi ortaya koyularak, sağlık harcamalarının toplumsal refah harcaması olduğu şeklindeki genel kabulün sorgulanmasına yol açılmaktadır.

Anahtar Kelimeler Bütçe Sınıflandırması, Devletin İşlevleri, Kamu Harcamaları, Sağlık Harcamaları

\section{JEL Kodu} H72, I1 1, I18

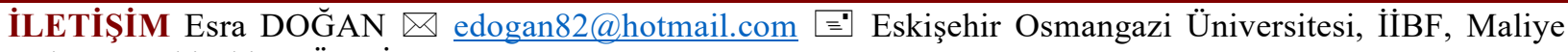
Bölümü, Eskişehir, TÜRKIYE 


\section{Health Expenditures in Turkey As Social Consumption Expenditures: A Theoretical Based Evaluation}

\begin{abstract}
The aim of this study is to evaluate the function of health expenditures as a public expenditures within the capitalist mode of production, based on James O'Connor's work titled Financial Crisis of the State. In this study, the position of the state within the capitalist relations of production is examined and accordingly, the reflection of the functions of the state to the state budget is revealed. This reflection in the state budget is revealed by the categorization of public expenditure items in the context of the functions of the state. While public expenditure items within the scope of the state budget have been classified by O'Connor as a whole, expenditure items are not subjected to a definite distinction in terms of their sub-levels. However, there are direct and indirect references to the category of some expenditure items such as health expenditures. In this study overall structure of the healthcare system in Turkey and health expenditures in the general budget is evaluated in order to determine the category of health expenditures in Turkey according to the budget categorization of O'Connor. Health expenditures of Turkey can not be classified under one category because of the fact that health expenditures under the general budget involved into two categories such as Central Government budget and Social Security Institution budget. With this study, the general acceptance that health expenditures are social welfare expenditures is questioned by revealing the importance of the distinction within the scope of the general budget for the health expenditures.
\end{abstract}

Keywords

Budget

Classification, Functions of the State, Public Expenditures, Health Expenditures JEL Classification H72, I1 1 , 118

\section{Giriş}

Kamu harcama kalemi olarak sağlık harcamaları küresel ölçekte olduğu gibi Türkiye'de de artış eğilimindedir. Sağlık harcamalarındaki bu artış, bir taraftan sağlık hizmetlerine erişimin dolayısıyla da sağlık hizmet arz ve talebindeki artışın bir göstergesi niteliğindeyken, bir taraftan da maliyet ve kontrol edilmesi gereken kamu harcama kalemi niteliğindedir. Sağlık hizmetleri arz ve talebindeki artış, sağlık sisteminin gelişmişliğinin bir göstergesi olarak kabul edilmektedir. Ancak sağlık sisteminde ortaya çıkan bu gelişmenin beraberinde getirdiği maliyet ise sağlık sisteminin sürdürülebilirliğinin sağlanmasına yönelik birtakım düzenlemelerin yapılması ihtiyacını beraberinde getirmektedir. 
Sağlık harcamaları, sağlığın temel bir insan hakkı olması nedeniyle diğer kamu harcama kalemleri gibi değerlendirilememektedir. Ancak yine de özellikle 21. yüzyılın temel kamu mali politikası niteliğindeki mali disiplin kaygısı sağlık harcamaları için de söz konusu olmaktadır. Buna bağlı olarak da diğer harcama kalemlerinde olduğu gibi sağlık harcamalarında da etkinlik, etkililik, verimlilik amacı ile uyumlu sağlık politikaları geliştirilmektedir. Bu durum bir taraftan yapılan düzenlemeler ile kendini gösterirken bir taraftan da söz konusu düzenlemelerin dolaylı bir sonucu olarak kabul edilebilecek bilimsel literatürdeki çalışmalar ile de ortaya koyulmaktadır. Bu doğrultuda literatürdeki çalışmalar genel olarak ele alındığında sağlık harcamalarının, etkinlik, ekonomik büyüme ve ekonomik kalkınma ile ilişkisi dolayısıyla da finansal sürdürülebilirlik bağlamında sağlık sistemine yönelik değerlendirmeler kapsamında içerildiği görülmektedir. Bu çalışmalardan özellikle Türkiye'yi içerenler incelendiğinde sağlık harcamaları ile ekonomik büyüme arasında, farklı bulgular (Çelik, 2020) da bulunmakla birlikte, uzun dönemli ilişki bulunduğu (Selim, Uysal, \& Eryiğit, 2014; Tıraşoğlu \& Yıldırım, 2012); sağlık harcamalarının kalkınma üzerinde pozitif etkiye sahip olduğu (Şaşmaz, Odabaş, \&Yayla, 2019; Arslan, Eren, \& Kaynak, 2016) sonuçlarına ulaşıldığı görülmektedir. Dolayısıyla da sağlık harcamaları temel makro ekonomik bir değişken niteliğine haiz olabilmektedir. $\mathrm{Bu}$ durum beraberinde mikro ekonomi açısından sağlık harcamalarını etkileyen faktörleri önemli hale getirmekle birlikte, mali düzenlemelerin gerekliliği olarak sağlık harcamaları için de etkinlik sorunsalına yol açmaktadır. $\mathrm{Bu}$ doğrultuda yapılan çalışmalarda gelir düzeyinin ülkeler arasındaki sağlık harcamalarının farklılaşmasına yol açan temel faktör olduğu ortaya koyulurken (Çalışkan, 2009); sağlık harcamalarında etkinlik sorunsalı bulunan ülkelerin de olduğu tespit edilmiştir (Konca, Gözlü, \& Çakmak, 2019). Makro ve mikro temelli bu çalışmalar bütün olarak değerlendirildiğinde, ortaya koyulan ilişkisellikler ve yapılan politika önerilerinin ise, mali disiplin kaygısıyla kurgulanan düzenlemelerin ampirik sorgulamasını içerdiği söylenebilir.

Diğer taraftan sağlık harcamaları, sahip olduğu kamu harcaması niteliğinin ötesinde toplumsal hatta varoluşsal bir içeriğe sahiptir. Nitekim Dünya Sağlık Örgütü (DSÖ) Anayasasına göre de sağlık "sadece hastalık ya da kusurun olmaması değil, fiziksel, zihinsel ve toplumsal refahın bütünüyle bulunması hali” olarak tanımlanmaktadır. Bununla birlikte kapitalist üretim biçimi dahilinde diğer kamu harcama kalemlerinde olduğu gibi sağlık harcamaları da kapitalist üretim biçiminin sürdürülebilirliğini, diğer bir ifade ile de sermaye birikim sürecinin sürekliliğini sağlamanın aracı niteliğine dönüşmektedir. Bu durum da sağlık harcamalarını temel varoluşsal ya 
da toplumsal bir sorunsal olmanın ötesinde ekonomik bir sorunsal olma haline indirgemektedir. Buna göre sağlık harcamaları, devletin toplumsal refahı sağlama işlevinin ötesinde işverenler üzerindeki maliyetin de azaltılarak işgücünün üretkenliğinin artırılmasının bir aracı haline gelmektedir. Nitekim bu durum, kapitalist üretim biçimi dahilindeki ilişkileri ve devletin konumunu eleştirel bir yaklaşımla inceleyen düşünürlerden olan James O’Connor tarafindan kapitalist üretim biçimi dahilindeki ilişkiler ağında bütçe kalemlerinin kategorizasyonu kapsamında incelenmektedir. $\mathrm{Bu}$ çalışma kapsamında da O'Connor'ın mali kriz kuramı kapsamında ele aldığı bütçe kategorizasyonundan hareketle Türkiye'deki sağlık harcamalarının incelenmesi amaçlanmaktadır. $\mathrm{Bu}$ amaç doğrultusunda yapılan değerlendirme ile sağlık harcamalarının mali disiplin kaygısıyla kurgulanan modellerdeki değişken olma niteliğinin ötesinde, esas olarak kapitalist üretim biçimi dahilinde aldığı rolün sorgulanması hedeflenmektedir. $\mathrm{Bu}$ doğrultuda çalışma iki temel bölümden oluşmaktadır. İlk bölümde O'Connor'ın mali kriz kuramı kapsamında ele aldığı bütçe kategorizasyonu hakkında bilgi verilmekte, bu kuramdan hareketle takip eden ikinci bölümde de Türkiye'deki sağlık sistemi değerlendirilmektedir.

\section{James O’Connor Kapsamında Bütçe Kategorizasyonuna Genel Bakış}

O’Connor kapsamında bütçe kategorizasyonu, 1973 tarihli "Devletin Mali Krizi” adlı eserinde yer alan ekonomi politik temelli bir bütçe teorisi niteliğindedir. Bu kuram, bütçenin teknik bir doküman ya da teknik bir süreç olarak dolayısıyla da ekonomik yapı ve politik bağlamdan bağımsız bir sorgulamasını değil; aksine Marx'ın ekonomi politik eleştirisinden hareketle ekonomik ve politik bağlamda 1970'li yılların ABD'si kapsamındaki mali kriz değerlendirmesinin odağını oluşturmaktadır.

Bütçe bağlamında mali krizin değerlendirilmesi, bütçe ile mali kriz arasında ampirik nitelikli nedensellik silsilesinin ötesinde, mevcut kapitalist üretim biçimi dahilindeki üretim ilişkileri ağının çelişkili yapısı temelinde gerçekleştirilmektedir. Kapitalist üretim biçimindeki sermaye emek ikiliği ve bu ikilik temelinde ortaya çıkan ilişkiler bağlamında devletin konumu, bütçe ve mali kriz üzerinde belirleyici olmaktadır. Nitekim O'Connor hiç kimsenin mali krizden ve bu krizin etkisini ağırlaştıran toplumsal krizin etkisinden kaçamayacağını düşünmektedir. Ayrıca O’Connor tarafindan yansıma ve sonuçlarını devlet bütçesi üzerinde gösteren çatışmalı yapının açıklığa kavuşturulmasını sağlayan mali krize yönelik düşünme ve eyleme faaliyetlerinde bulunulabilmesi için yeni bir yol gerekli görülmektedir. Bununla birlikte O’Connor devlet bütçesi 
teorisine ve bütün olarak politik ekonomi ve toplumun anlamının açığa çıkarılabilmesi için bir yönteme ihtiyaç olduğunu belirtmektedir. Kapitalist üretim ilişkileri ağındaki çelişkili yapıda mali yapı ile ilişkili olan pek çok sorunun çözüme kavuşturulması ise ekonomi politik analiz içeren yol, yöntem ve teori aracılığıyla sağlanabilecektir (O'Connor, 2001). Buradan hareketle O'Connor'ın, mali krizin anlaşılmasına olanak sağlayan yapının çözümlemesinin, esas olarak çatışmalı ilişkiler ağında devletin ne şekilde konumlandırıldığı ve bu konumun devlet bütçesine ne şekilde yansıdığı hususunun açığa çıkarılmasına bağladığı söylenebilir. Buna bağlı olarak da kapitalist üretim biçimi bağlamında "sermayenin alanında ortaya çıkan krizin kamu maliyesine yansıması" (Gürkan \& Karahanoğulları, 2013) şeklinde ifade edilen devletin mali krizi, devletin konumlandırıldı̆̆ noktanın devlet bütçesi üzerindeki yansımanın değerlendirilmesi aracılığıyla ele alınmaktadır.

O’Connor kapitalist üretim biçimi dahilindeki yapılanmada devletin, ikili bir yapıya sahip olan sermayenin tekelci kesimi ve rekabetçi kesimi ile her iki kesimde istihdam edilen, dolayısıyla emeğin de kendi içinde ikili bir ayrıma sahip olduğu bir ortamda konumlandığını belirtmektedir. Buna bağlı olarak da sermaye emek ikiliği ve hatta sermaye ve emeğin kendi içindeki ikiliği ayrımı temelinde devletin üstlendiği çelişkili işlevsellik ile kamu maliyesine ilişkin alan, çatışmalı çıkarların söz konusu olduğu sermaye ve emeğin eşanlı koordine edilmeye çalışıldığı bir alan halini almıştır. Buna paralel olarak, söz konusu kapitalist üretim biçimi/sistemi çerçevesinde şekillenmiş bir "devlet algısı" bulunmaktadır. Farklı üretim biçimlerinde/sistemlerinde devletin kazandığı anlam, kendisine yüklenen rol/görev nedeniyle değişkenlik göstermekle birlikte kapitalist üretim biçimi/sisteminde kazandığı anlamı; Engels'in “Ailenin, Özel Mülkiyetin ve Devletin Kökeni” adlı eserinde "Devleti, görünüşte toplumun üzerinde yer alan ancak yerleşik ekonomik ve toplumsal düzeni sürdürmeye yarayan güç” olarak belirttiği şekliyle kabul edebiliriz. Bu yapı dahilinde devlet de sermaye birikiminin sürekliliğini ve halihazırdaki sisteminin meşruiyetini sağlama şeklinde ikili bir işleve sahip hale gelmektedir. Sermaye birikiminin sürekliliğinin sağlanması, kapitalist üretim biçimi bağlamında devletin tekelci ve rekabetçi kesimler arasındaki temel işlevi halini alırken; bu sistemin gerektirdiği meşruiyet ihtiyacı da devletin meşruiyet işlevi halini almaktadır. Esasında kapitalist üretim biçiminin oluşturduğu sisteminin sürekliliğini temin eden ancak diğer taraftan çelişkili bir yapıyı da içinde barındıran devletin bu ikili işlevi, O’Connor tarafından kapitalist üretim biçimi dahilindeki devlet bütçesine yönelik kategorizasyon temelli bir kuramın geliştirilmesine yol açmıştır. 
O’Connor tarafından geliştirilen mali kriz kuramına göre, devlet faaliyetlerinin gerektirdiği harcamalar devletin ikili işlevi bağlamında kategorize edilmektedir. Buna göre devletin sermaye birikimi işlevine yönelik harcamaları "toplumsal sermaye harcamaları" olarak adlandırılmakta olup; bu harcamalar da kârlılık oranlarının yükselmesini, işgücünün verimliliğini yükselten proje ve hizmetler ve emeğin yeniden üretim maliyetini düşüren proje ve hizmetler aracılığıyla temin eden sırasıyla "toplumsal yatırım harcamaları" ve "toplumsal tüketim harcamaları" şeklinde adlandırılmaktadır. Devletin meşruiyet işlevine yönelik harcamalar ise "toplumsal gider harcamaları" olarak ifade edilmektedir. Bu harcamalar dolaylı olarak dahi üretken harcamalar olmayıp; toplumsal uyumu temin eden ve bu uyumu güvenliğe yönelik harcamalar ile toplumsal refaha yönelik harcamaları eşanlı içerecek şekilde baskı, zor unsuruna ve ikna yöntemine dayandırarak ikili bir ayrım temelinde gerçekleştirmektedir (O'Connor, 2001).

O’Connor tarafından bütçe dahilinde yapılan kategorizasyon ayrıca kapitalist üretim biçimindeki aktörlerin kategorizasyonu ile tamamlanmıştır. Kapitalist üretim biçimi/sisteminde ekonomik faaliyetlerin üç temel aktör çerçevesinde şekillendiği görülmektedir. Bu aktörler, devlet, tekelci kesim ve rekabetçi kesimdir. Bu kesimlerdeki gerek ilgili özne unsurları açısından gerekse kapitalist üretim biçimi/sisteminin devamlılığı açısından önemi nedeniyle verimlilik ve ücret düzeylerine bakıldığında, bu düzeylerin rekabetçi kesimde düşükken tekelci kesimde yüksek olduğu görülmektedir. Ayrıca rekabetçi kesimdeki işçilerin geçici nitelikte olduğu, istihdamın daha düşük olduğu ve işçilerin örgütlü bir yapısının bulunmadığı, ancak aksine tekelci kesimdeki işçilerin kalifiye oldukları ve örgütlü bir yapılarının bulunduğu görülmektedir. Kapitalist üretim biçimi/sisteminde her iki kesim birbirine karşılıklı bağımlı bir yapıda iken, devlet de ekonomik faaliyet çerçevesinde bu gruplara üretim düzeyinde bağımlılık göstermektedir. Dolayısıyla birbirine bağlı durumdaki bu üçlü yapının kapitalist üretim biçiminin temel öznelerini oluşturduğu söylenebilir.

$\mathrm{Bu}$ çerçevede O’Connor tarafından geliştirilen mali kriz kuramı, bütçede yer alan kalemlerin sınıflandırılmasının ötesinde, kapitalist üretim biçimi dahilindeki örgütsel yapının bütçe üzerindeki yansımasını ortaya koymaktadır. Buna göre kapitalist sistemin sürekliliğinin temini, bir taraftan devletin sistem içindeki aktörleri desteklemesi ile bir taraftan da kendi meşruiyetini, dolayısıyla da sistemin meşruiyetini sağlayabilmesi ile gerçekleşebilmektedir. Bu doğrultuda devlet, rekabetçi kesim ve özellikle de tekelci kesimdeki sermaye birikiminin devamlılı̆̆ını 
sağlamaya yönelik toplumsal sermaye harcamaları yaparken; kendisinin ve dolayısıyla da sistemin meşruiyetine yönelik de toplumsal gider harcamaları yapmaktadır.

\section{Bütçe Kategorizasyonu Bağlamında Türkiye'deki Sağlık Harcamaları}

O’Connor'ın mali kriz kuramı kapsamında yer alan bütçe kategorizasyonunda kamu harcama kalemlerinin bütün olarak sınıflandırılması yapılmakla birlikte, bu sınıflandırmada harcama kalemleri alt düzeyleri itibariyle kesin bir ayrıma tabi tutulmamaktadır. Ancak sağlık harcaması gibi birtakım harcama kalemlerinin kategorisine ilişkin de doğrudan ve dolaylı göndermeler bulunmaktadır. Buradan hareketle O'Connor'ın yaptığı bütçe kalemleri arasındaki kategorizasyonuna göre Türkiye' deki sağlık harcamalarının kategorisini belirleyebilmek amacıyla öncelikle Tükiye'deki sağlık sisteminin genel yapısı, sonrasında ise bu yapı bağlamında genel bütçe kapsamındaki sağlık harcamalarının değerlendirmesi yapılmaktadır.

\subsection{Tarihsel Süreç ve Genel Yapı Bağlamında Türkiye'deki Sağlık Sistemi}

Türkiye'de ilk kurulan bakanlıklardan olan Sağlık Bakanlığı 1920 yılında kurulmuş ve yine aynı yıl Tababet-i Adliye Kanunu çıkarılmıştır. Takip eden süreçte Cumhuriyetin ilanı ile ise sağlık alanında halen yürürlükte olan birçok kanun çıkarılmıştır ${ }^{1}$. Bu dönemin temel sağlık politikası alanları; sağlık hizmetlerinin plan ve programı ile yönetiminin tek elden yürütülmesi, hizmet alanın merkezi yönetimde koruyucu hekimliğin, yerel yönetimlerde ise tedavi edici hekimliğin bulunması şeklinde ayrılması, sağlıkta insan gücü yetiştirilmesi ve bulaşıcı hastalıklarla mücadele şeklinde oluşturulmuştur. 1945 sonrasında ise sağlık sisteminde; sağlık hizmet sunumunun örgütlenmesi, sağlık hizmet arzının yaygınlaşması ve özellikle sağlık çalışanlarına yönelik yasal düzenlemelerin yapılması şeklinde düzenlemeler gerçekleştirilmiştir. Bununla birlikte bu dönemin belirgin özelliklerinden biri, 1946 yılında İşçi Sigortaları İdaresinin (Sosyal Sigortalar Kurumu) kurulmasıyla sigortalı işçiler için sağlık kurumlarının açılmaya başlanması ve Emekli Sandığının kuruluşuna yönelik çalışmalar ile sosyal güvenliğin kapsamının genişletilmeye başlamasıdır (Akdăg, 2012).

Türkiye'deki mevcut sağlık sistemi üzerinde belirleyici nitelikte olan düzenlemelerin ise 1960 sonrası dönemde yapıldığg söylenebilir. Nitekim Türkiye'de sağlık sisteminin yapısına

\footnotetext{
${ }^{1}$ Bu kanunlar; 992 sayılı Bakteriyoloji ve Kimya Laboratuvarları Kanunu (1927), 1219 sayılı Tababet ve Şuabatı Sanatlarının Tarzı İcrasına Dair Kanun (1928), 1262 sayılı İspençiyari ve Tıbbi Müstahzarlar Kanunu (1928), 1593 sayılı Umumi Hıfzıssıhha Kanunu (1930), 3153 sayılı Radyoloji Radyum ve Elektrikle Tedavi ve Diğer Fizyoterapi Müesseseleri Hakkında Kanun (1937) şeklindedir.
} 
bakıldığında sağlığın anayasal bir hak olduğu ve devletin işlevi niteliğine sahip olduğu görülmektedir. Bu durum, 1961 Anayasasında "Sağlık Hakkı" başlığı altında devletin sağlığa yönelik işlevi "Devlet, herkesin beden ve ruh sağlığı içinde yaşayabilmesini ve tıbbî bakım görmesini sağlamakla ödevlidir. Devlet, yoksul veya dar gelirli ailelerin sağlık şartlarına uygun konut ihtiyaçlarını karşılayıcı tedbirleri alır” (Madde49) şeklinde ifade edilmiştir. Anayasaya göre devlet, sağlık hakkının varlığını temin eden temel aktör niteliğinde olup, bu durum, yürürlük tarihi 12.01.1961 olan 224 sayılı Sağlık Hizmetlerinin Sosyalleştirilmesi Hakkında Kanun ile de uygulanabilirlik kazanmıştır. Bu doğrultuda kanunun amaç maddesi (Madde 1) "İnsan Hakları Evrensel Beyannamesinde bir hak olarak tanınan sağlık hizmetlerinden faydalanmanın sosyal adalete uygun bir şekilde ifasını sağlamak maksadiyle tababet ve tababetle ilgili hizmetler bu kanun çerçevesinde hazırlanacak bir program dahilinde sosyalleştirilecektir" şeklinde oluşturulmuştur. $\mathrm{Bu}$ amaç doğrultusunda kanunun uygulanması ise, sağlık evleri, sağlık ocakları, ilçe ve il hastanelerinin açılmasıyla sağlık hizmetlerinin sunumunda kademeli, il içerisinde bütünleştirilmiş bir yapı aracıllı̆ıyla gerçekleştirilir hale gelmiştir (Çavmak \& Çavmak 2017: 50). Bununla birlikte devletin sağlığa yönelik işlevi, 1982 Anayasasında "Sosyal ve Ekonomik Haklar ve Ödevler"başlı̆̆ altında "Herkes, sağlıklı ve dengeli bir çevrede yaşama hakkına sahiptir. Çevreyi geliştirmek, çevre sağlığını korumak ve çevre kirlenmesini önlemek Devletin ve vatandaşların ödevidir. Devlet, herkesin hayatını, beden ve ruh sağlığı içinde sürdürmesini sağlamak; insan ve madde gücünde tasarruf ve verimi artırarak, işbirliğini gerçekleştirmek amacıyla sağlık kuruluşlarını tek elden planlayıp hizmet vermesini düzenler. Devlet, bu görevini kamu ve özel kesimlerdeki sağlık ve sosyal kurumlarından yararlanarak, onları denetleyerek yerine getirir. Sağlık hizmetlerinin yaygın bir şekilde yerine getirilmesi için kanunla genel sağlık sigortası kurulabilir" (Madde 56) ve "Herkes, sosyal güvenlik hakkına sahiptir. Devlet, bu güvenliği sağlayacak gerekli tedbirleri alır ve teşkilatı kurar” (Madde 60) şeklinde belirlenmiştir. 1961 Anayasasından farklı olarak sağlık sistemi sağlığın kendisinden kaynaklanan "sağlık hakkı" olarak değil, sağlığın ilişkili olduğu "sosyal ve ekonomik hak ve ödev" bağlamında ele alınmış, dolayısıyla da sağlığın ilişkili olduğu bağlam genişletilmiştir. Bu bağlam genişliği, sağlığın sadece devletin işlevi ve ödevi olma halinden, sağlık hizmet talebinde bulunanların da ödevi haline getirilmesi ve sağlık hizmet arzının kamu hizmeti olarak sınırlandırılmayıp özel hizmet sunumunun da anayasal bir nitelik almasıyla gerçekleştirilmiştir. Bağlamın genişletilmesiyle birlikte devletin rolü ise, sağlık hizmet arzının temel aktörlüğünden, sağlı hizmet arzının düzenleyicisi ve 
denetleyicisi olma haline dönüşmüştür. Ancak bu dönüşüm sadece devletin işlevinin değişmesi değil; sağlık hizmeti talep edenlerin bu hizmete erişebilirlik düzeyine ilişkin de bir dönüşüm niteliğindedir. Nitekim 224 sayılı Sağlık Hizmetlerinin Sosyalleştirilmesi Hakkındaki Kanunda "vatandaşların sağlık hizmetleri için ödedikleri prim ile amme sektörüne ait müesseselerin bütçelerinden ayrılan tahsisat karşılı̆̆ herçeşit sağlık hizmetlerinden ücretsiz veya kendisine yapılan masrafın bir kısmına iştirak suretiyle eşit şekilde faydalanmalarıdır” şeklinde tanımlanan sağlık hizmetlerinin sosyalleştirilmesinin de, devletin sağlığa yönelik işlevindeki daralma ile beraber uygulanabilirliği azalmıştır. Bu durum sağlığın "sosyal ve ekonomik hak ve ödev" bağlamına taşındığı 1982 Anayasasında anayasal nitelik kazanmakla birlikte, 1963-1967 dönemine ilişkin Birinci Beş Yıllık Kalkınma Planındaki sağlığa hizmetlerine yönelik hedefler ve bu hedeflere yönelik tedbirler kapsamında da yer almıştır. Sağlık hizmetleri her ne kadar Sağlık Bakanlığı bünyesinde içerilse de söz konusu hedef ve tedbirler arasında hastanelerin döner sermayeli kurumlar haline getirilmesi, özel sektörün hastane kurmak için teşvik edilmesi ve sağlık hizmetlerini de kapsayacak şekilde bir sosyal güvenlik sigortası sisteminin oluşturulması maddeleri yer almıştır. Bu duruma bağlı olarak da 224 sayılı Sağlık Hizmetlerinin Sosyalleştirilmesi Hakkındaki Kanunun yürürlüğe girdiği andan itibaren sosyalleştirmenin içeriği, sağlık hizmetlerinin devletleştirilmesi şeklini değil; sağlık hizmet talebinde bulunanların bu talepte bulunabilmelerinin sağlanması şeklini almıştır.

1982 Anayasasını ve sağlığın anayasal olarak "sosyal ve ekonomik hak ve ödev" bağlamında ele alınmasını takiben 07.05.1987 tarihinde 3359 sayılı Sağlık Hizmetleri Temel Kanunu düzenlenmiştir. Bu kanunun temel esasları arasında da Anayasa ile uyumluluk gösterecek şekilde "Koruyucu sağlık hizmetlerine öncelik verilmek suretiyle kamu ve özel bütün sağlık kurum ve kuruluşlarının kurulması ve işletilmesinde kaynak israfı ve atıl kapasiteye yol açılmaksızın gerektiğinde hizmet satın alarak kaliteli hizmet arzı ve verimliliği esas alınır. Sağlık ve Sosyal Yardım Bakanlığı ilgili Bakanlığın muvafakatını alarak, kamu ve özel bütün sağlık kurum ve kuruluşlarına koruyucu sağlık hizmeti görevi verir ve bu kurum ve kuruluşların bütün sağlık hizmetlerini denetler" maddesi (Madde 3) yer almaktadır. Bu madde ile de sağlık hizmet arzının genişleyen yapısı ve bu yapı dahilinde devletin düzenleyici ve denetleyici konumuna vurgu yapılmıştır. Böylelikle de 1982 anayasası ile sağlıkta sosyal devletçi yaklaşımın değiştirilmesi sürecinin temel adımı anayasal bağlamda sağlanırken, bu sürecin genel çerçevesi de 3359 sayılı Sağlık Hizmetleri Temel Kanunu ile çizilmiştir (Erdoğdu, 2013). Bu süreç dahilinde 1990’lı 
yıllarda sosyal güvenlik kurumlarının tek çatı altında toplanarak Genel Sağlık Sigortasının kurulması, birinci basamak sağlık hizmetlerinin aile hekimliği çerçevesinde geliştirilmesi, hastanelerin özerk sağlık işletmelerine dönüştürülmesi, Sağlık Bakanlığının koruyucu sağlık hizmetlerine öncelik veren sağlık hizmetlerini planlayıp denetleyen bir yapıya kavuşturulmasına yönelik reform çalışmalarında bulunulmuştur. Ancak bu reform çalışmaları 16.11.2002 tarihinde açıklanan 58. Hükümet Acil Eylem Planında "Herkese Sağlık" başlığı altında "Sağlık Bakanlığı'nın idari ve fonksiyonel açıdan yeniden yapılandırılması, tüm vatandaşların genel sağlık sigortası kapsamı altına alınması, sağlık kuruluşlarının tek çatı altında toplanması, hastanelerin idari ve mali açıdan özerk bir yapıya kavuşturulması, aile hekimliği uygulamasına geçilmesi, anne ve çocuk sağlığına özel önem verilmesi, koruyucu hekimliğin yaygınlaştırılması, özel sektörün sağlık alanına yatırım yapmasının özendirilmesi, tüm kamu kuruluşlarında alt kademelere yetki devri, kalkınmada öncelikli bölgelerde yaşanan sağlık personeli eksikliğinin giderilmesi, sağllk alanında e-dönüşüm projesinin hayata geçirilmesi” hedefleri çerçevesinde sağlıkta dönüşüm programı halini almıştır (Sağlık Bakanlı̆̆ı, 2019). Bu hedefler doğrultusunda dolayısıyla da sağlıkta dönüşüm programı çerçevesinde gerçekleştirilen en kapsamlı uygulama da 31.05.2006 tarih ve 5510 sayılı Sosyal Sigortalar ve Genel Sağlık Sigortası Kanununun 2008 yılında yürürlüğe girmesiyle gerçekleştirilmiştir. Böylelikle sağlık hizmeti arz ve talep tarafinda bulunanların tamamı sosyal güvenlik şemsiyesi altında toplanmıştır. Bu doğrultuda sağlık hizmeti talep ve arz edenlere ilişkin yapı, doğrudan doğruya etkilenmiştir. İlk olarak sağlık hizmeti talep edenler ele alındığında sağlık hizmetinin talep kısmında yer alanların tamamının zorunlu olarak sigorta kapsamına dahil edildiği görülmektedir. Nitekim bu durum, kanunun 60 maddesi kapsamında, genel sağlık sigortası kapsamında olanlar altı ana başlık altında sayılırken, bu başlıklar kapsamında yer almayanların da başka ülke sigortasından yararlanma hakkı bulunmaması koşuluyla genel sağlık sigortası kapsamında yer alacağı şeklinde belirtilmiştir. Buna bağlı olarak da genel sağlık sigortası kapsamındaki herkes prim yükümlüsü haline gelmiş, hatta bu durum Madde 52 kapsamında da belirtildiği gibi bakmakla yükümlü olunan kişinin isteğe bağlı sigortalı olması halinde de geçerlilik kazanmıştır. Prime esas kazancın belirlenmesinde ise hangi kategori bağlamında genel sağlık sigortası kapsamında yer alındığına bağlı olarak uygulama değişkenlik göstermektedir (Madde 80). Bununla birlikte Madde 80/b kapsamında “Ayni yardımlar ve ölüm, doğum ve evlenme yardımları, görev yollukları, seyyar görev tazminatı, kıdem tazminatı, iş sonu tazminatı veya kıdem tazminatı mahiyetindeki toplu ödeme, keşif ücreti, ihbar ve kasa tazminatları ile Kurumca tutarları yıllar 
itibarıyla belirlenecek yemek, çocuk ve aile zamları, işverenler tarafindan sigortalılar için özel sağlık sigortalarına ve bireysel emeklilik sistemine ödenen ve aylık toplamı asgari ücretin \% 30’unu geçmeyen özel sağlı sigortası primi ve bireysel emeklilik katkı payları tutarları, prime esas kazanca tabi tutulmaz" şeklinde özel sağlık sigortası kapsamında olma halinin lehine bir düzenleme bulunmaktadır. Ancak sağlık hizmeti talep edenler açısından Madde 80 kapsamındaki kategorizasyon dahilindeki prim ödemesi yeterli değildir. Ayrıca Madde 68 ve Madde 69 bağlamında koşulları ayrıştırılan katkı payı ödemesi de gereklidir.

İkinci olarak sağlık hizmeti arzı ele alındığında sağlık hizmetlerinin sunum şeklinin değiştirildiği görülmektedir. Bu durum Madde 73 kapsamında "sağlık hizmetleri Sosyal Güvenlik Kurumu Başkanlığı ile yurt içindeki veya yurt dışındaki sağlık hizmeti sunucuları arasında yapılan sözleşmeler yoluyla ve/veya bu Kanun Hükümlerine uygun olarak genel sağlık sigortalısı ve bakmakla yükümlü olduğu kişileri sözleşmesiz sağlık hizmeti sunucularından satın aldıkları sağlık hizmeti giderlerinin ödenmesi suretiyle sağlanır” şeklinde karşılık bulmaktadır. Sağlık, Sağlık Bakanlığı yerine Sosyal Güvenlik Kurumu Başkanlığının bünyesinde toplanmış ve bu kapsam dahiline alınan sağlık hizmet sunumunun sözleşmeli sağlık hizmet sunucularını da içerecek şekilde genişletilmiştir. Bu genişleme ile birlikte Madde 70 kapsamında "Aile hekimi birinci basamak hizmet sunucuları içinde yer alır” şeklinde tanımlanan aile hekimliği uygulaması sağlık sistemine dahil edilmiştir.

Bu çerçevede O’Connor'dan hareketle Türkiye'deki sağlık sisteminin tarihsel süreci genel itibariyle ele alındığında, 1980'li yıllara kadar sağlık sisteminin tek elden yürütülmeye çalışılan bütüncül bir yapıya sahip olduğu ve toplumsal refah niteliğinin ön planda olduğu söylenebilir. $\mathrm{Bu}$ durum söz konusu dönemde sağlık harcamalarının toplumsal gider harcaması niteliğinin ön planda olmasına yol açmaktadır. Bununla birlikte gerek 1940’lı yıllarda sosyal güvenlik sistemine yönelik gelişmelerin başlaması gerekse kalkınma planları ile sağlık sigortasına yönelik politika hedeflerinin belirginlik kazanması takip eden süreçlerde sağlık sisteminde ortaya çıkacak dönüşümün temellerini oluşturmuştur. Nitekim 1982 Anayasası ve bu doğrultuda yapılan yasal düzenlemeler ile temelde sağlık sisteminin bütüncül yapısının değiştirilmesine bağlı olarak sağlık harcamalarında da kategorik bir değişim ortaya çıktığı söylenebilir. Buna göre sağlık hizmet sunumu ile sağlık hizmetlerinin finansmanının ayrıştırılması şeklinde ortaya çıkan dönüşüm, sağlık harcamalarının toplumsal refaha yönelik toplumsal gider harcaması olma niteliğinin de sorgulanır hale gelmesine neden olmuştur. Bu durum özellikle de, yukarıda ilgili maddeler kapsamında da 
belirtildiği gibi 5510 sayılı Sosyal Sigortalar ve Genel Sağlık Sigortası Kanununu ile sağlığın finansmanının gelire esas prim kazançlarına dayanan bir hal alması ile belirginleşmiş̦tir. Buna bağlı olarakdevam eden bölümde, Türkiye'deki sağlık harcamalarının toplumsal refah harcaması, O’Connor'1n kategorizasyonu kapsamında da toplumsal gider harcaması olma niteliğinin sorgulanmasına yönelik, genel bütçe kapsamındaki sağlık harcamalarına yönelik bir değerlendirme yer almaktadir.

\subsection{Genel Bütçe Kapsamındaki Sağlık Harcamalarının Bütçe Kategorizasyonu Bağlamında Sinıflandırılması}

Türkiye'deki sağlık sisteminin tarihsel süreçte geçirdiği dönüşüm ve gelinen nokta, O’Connor tarafından mali kriz kuramı kapsamında ifade edilen devletin birikim ve meşruiyet işlevlerinin çelişkili birlikteliğini açık hale getirmektedir. Bu durumun değerlendirilmesi amacıyla öncelikli olarak O’Connor'ın kuramı kapsamında sağlık ve sağlığa yönelik harcamaların bütçede hangi kapsamda yer aldığı ortaya konulacaktır. Ancak O’Connor tarafından da belirtildiği gibi devletin ikili bir işleve sahip olması ve bu işlevler dahilinde kategorize edilmiş bir yapı bulunsa da, harcama kalemlerinin tamamını sadece tek bir kategori bağlamında ele almak mümkün olamamaktadır. Bazı harcamalar devletin her iki işlevselliği bağlamında da ortaya çıkabilmektedir (O'Connor, 2001: 7). Nitekim sağlık hizmetlerine yönelik yapılan harcamalar için de benzer durum geçerlidir. Sağlık harcamaları kapsamında doğrudan doğruya toplumsal refahın arttırılmasına yönelik harcamalar meşruiyet harcaması niteliğindeyken, işgücünün üretkenliğinin artırılmasına imkan tanıyan harcamalar da üretken harcama olarak birikim harcamaları kategorisinde yer alabilmektedir.

\subsubsection{Merkezi yönetim bütçesi kapsamında sağlık harcamaları}

Türkiye'de merkezi yönetim bütçesi kapsamında yer alan sağlık harcamaları göz önünde bulundurulduğunda sağlık hizmetlerinin işgücünün üretkenliğini artırmaya yönelik birikim harcamaları kategorisinde yer alması gerektiği düşünülmektedir (Bıçakc1, 2017). Bu doğrultuda Türkiye'deki sağlık sisteminin yapısı bağlamında merkezi bütçe kapsamında yer alan sağlık hizmetlerine yönelik değerlendirme yapabilmek amacıyla aşağıda yer alan tablo sunulmuştur ${ }^{2}$.

\footnotetext{
²Tablo kapsamında oluşturulan kategorizasyon O'Connor'ın kuramı bağlamında Bıçakcı (2017) tarafından hazırlanan çalışmaya dayanmaktadır. Ancak bu çalışma kapsamında sadece sağlık hizmetlerinin merkezi yönetim bütçe
} 
Tablo 1

Merkezi Yönetim Bütçe Harcamaları (\%)

\begin{tabular}{|c|c|c|c|c|c|c|c|c|c|c|c|c|c|}
\hline üt & 06 & 07 & 08 & 9 & & & & & 14 & 15 & & 17 & \\
\hline & & & & & & & & & & & 8,45 & & \\
\hline & & & & 32,91 & 0,39 & 29,23 & 9,08 & 28,04 & 28,04 & 27,95 & 25,79 & 25,22 & 27,24 \\
\hline & & & & & & & & & & & & & 500 \\
\hline & 5,90 & & & & & & & & & 7,67 & & & \\
\hline & 0,07 & & & & & & & & & & & & \\
\hline & 48,00 & 50,79 & 51,94 & 55,51 & 8,00 & 58,30 & 58,44 & 59,72 & & & 61,55 & 62,28 & \\
\hline & 11,86 & 11,62 & 12,83 & 12,32 & 14,03 & 14,00 & 13,85 & 14,15 & 13,87 & 14,50 & 13,31 & 13,41 & 13,47 \\
\hline & 2,16 & & 1,67 & & 2,23 & 1,53 & 1,52 & 1,74 & 1,27 & 1,18 & 1,00 & 1,34 & 1,29 \\
\hline & & & & & & 5,9 & & 4, & & 4,9 & & 5,19 & 4,84 \\
\hline & 1,58 & & 1,70 & & & 2,10 & 2,06 & 2,17 & 2,26 & 2,18 & 2,04 & 2,04 & 1,94 \\
\hline & 12,47 & 12,60 & 3,43 & 13,33 & 14,09 & 15,43 & & 15,89 & 16,87 & 17,16 & 17,83 & 16,77 & 10, \\
\hline & 14,72 & 17,13 & 16,59 & 20,90 & 20,35 & & 21,03 & & & & 22,49 & 23,52 & \\
\hline & & & & & & & & & & & & 100 & 100 \\
\hline
\end{tabular}

Kaynak. Hazine ve Maliye Bakanlığı Merkezi Yönetim Bütçe İstatistikleri kullanılarak hesaplanmıştır.

Merkezi yönetim gider bütçesi kapsamında sağlık hizmetlerinin payına bakıldığında, toplam harcamalar içindeki payının oldukça düşük (\%6'nın altında) olduğu ve yıllar itibariyle de düşüş eğilimi gösterdiği görülmektedir. $\mathrm{Bu}$ düşüşün sebepleri Sağlık Bakanlığı tarafından gerçekleştirilen kamu görevlilerin sağlık harcamalarının 2010 yılından itibaren, yeşil kart sahiplerinin sağlık harcamalarının ise 2012 yılından itibaren SGK' na devredilmesidir. Bunun üzerine 2012 yılından itibaren sadece milletvekillerinin, öğrencilerin, er ve erbaşlar ile tutuklu ve hükümlülere ait sağlık harcamaları merkezi yönetim bütçesi kapsamında yer almıştır. Bununla birlikte merkezi bütçe kapsamındaki sağlık harcamalarının payında ortaya çıkan yükselme ise aile hekimliği sisteminin 2010 yılında 81 ilin tamamında uygulanmaya başlanmasından kaynaklanmaktadır. Bu doğrultuda merkezi bütçe kapsamında sağlık hizmetleri kapsamda yapılan harcamaların yıllar itibariyle durumu aşağıdaki şekil aracılığıyla özetlenmektedir.

harcamaları payı ile ilgilenilmekte olup, merkezi bütçeye yönelik söz konusu kategorizasyona sağlık hizmetlerine yönelik harcamaların payına yönelik değerlendirme yapılabilmesi amacıyla yer verilmiştir. 


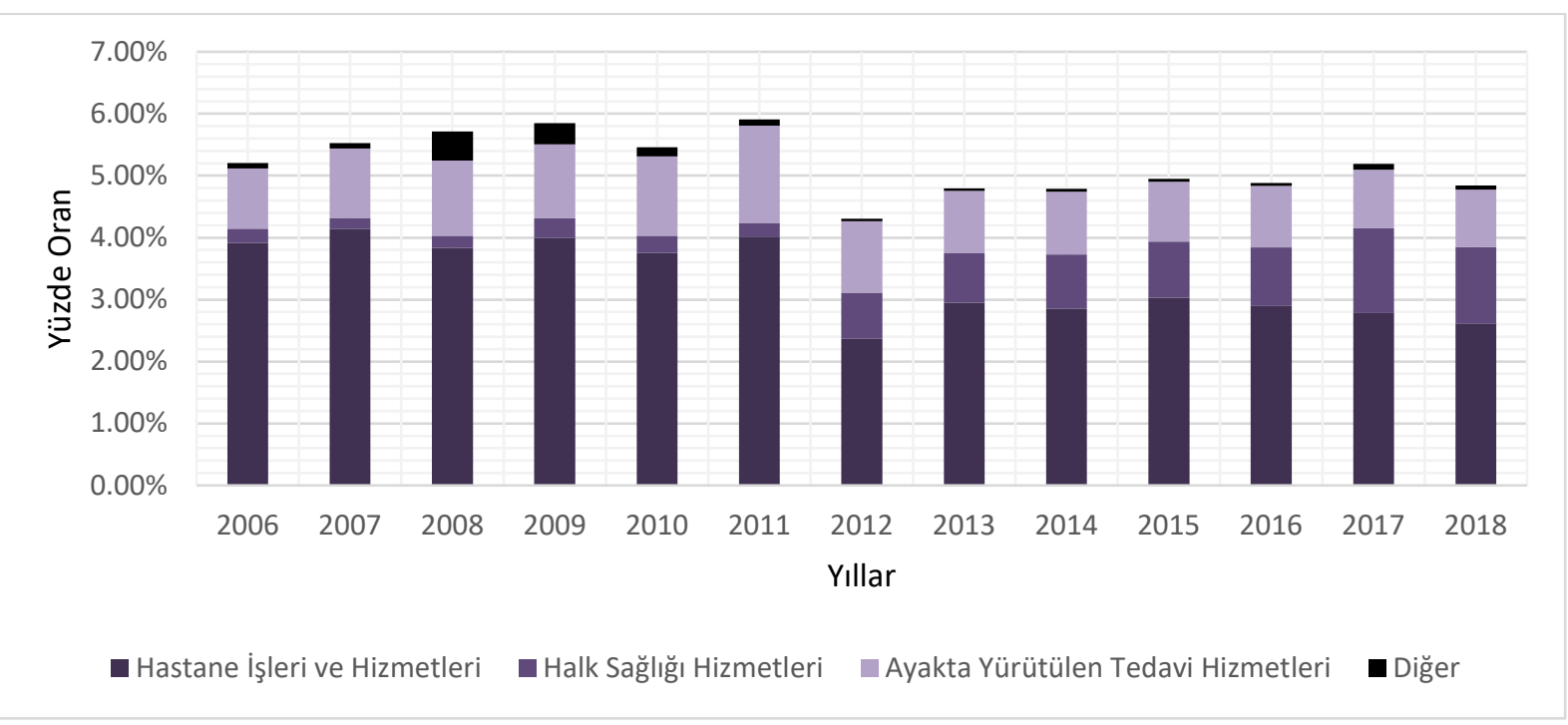

Şekil 1. Merkezi Yönetim Bütçe Giderleri Kapsamında Sağlık Hizmetlerinin Toplam Giderler İçindeki Payı (2006-2018). Hazine ve Maliye Bakanlığı Merkezi Yönetim Bütçe İstatistikleri kullanılarak hesaplanmıştır.

Şekilde görüldüğü gibi sağlık hizmetleri ağırlıklı olarak hastane işleri ve hizmetleri, halk sağlığı hizmetleri ve ayakta yürütülen tedavi hizmetlerinden oluşmaktadır. Merkezi bütçe kapsamındaki sağlık hizmetleri harcama miktarında yıllar itibariyle genel bir artış eğilimi bulunmaktadır. Ancak 2012 yılında halk sağlığı hizmetlerindeki belirgin artışa rağmen yeşil kart sahiplerinin harcamalarının SGK' na devriyle 2012 yılında net bir düşüş ortaya çıkmıştır. Buna bağlı olarak özelikle 2012 yılından itibaren merkezi bütçe kapsamındaki sağlık hizmetleri kapsamındaki harcama kalemlerinin kendi içlerindeki dağılımı önemli ölçüde değişim göstermiştir. Merkezi bütçe kapsamındaki sağlık harcamalarının önemli bir kısmını oluşturan hastane işleri ve hizmetlerinin payı, 2012 yılından itibaren yeşil kartlıların SGK' na devriyle birlikte önemli ölçüde azalmıştır. Ancak aile hekimliği modelinin 81 ilde yaygınlaşmasıyla birlikte birinci basamak sağlık hizmetlerinde dolayısıyla da halk sağlığı hizmetleri ve ayakta yürütülen tedavi hizmetlerinin payında belirgin ölçüde artış ortaya çıkmıştır.

$\mathrm{Bu}$ çerçevede merkezi yönetim bütçesi kapsamındaki sağlık harcamaları bütün olarak ele alındığında sağlık alanında gerçekleştirilen düzenlemeler ile birlikte merkezi bütçe kapsamında gerçekleştirilen sağlık harcamalarının önemli miktarda azaldığı görülmektedir. Bununla birlikte merkezi yönetim bütçesi kapsamındaki sağlık harcamalarının bütçe kategorizasyonu bağlamında iki farklı açıdan ele alınması uygun olacaktır. İlk olarak öğrenciler, er ve erbaşlar ile tutuklu ve 
hükümlülere ilişkin sağlık harcamaları ele alındığında bu harcamaların sağlık sisteminin geçirdiği dönüşümün bir sonucu olarak merkezi yönetim bütçesi kapsamında bulunduğu söylenebilir. Sağlık hizmetleri sunumunda prime esas kazanç sistemine geçilmesi ile birlikte sosyal güvenlik kapsamında içerilemeyen gruplara yönelik sağl1k harcamaları merkezi yönetim bütçesi kapsamında kalmıştır. Sosyal güvenlik sistemi kapsamında yer almayan bu gruplar için sunulan sağlık hizmetinde, işgücünün üretkenliğini artırma amacının aksine, sağlı̆̆ın karşılık geldiği insani hak özelliğinin sonucu olarak toplumsal refah harcaması niteliği bulunduğu söylenebilir. Buna bağl1 olarak da söz konusu sağlık harcamaları bütçe kategorizasyonu bağlamında da devletin meşruiyet işlevine yönelik toplumsal gider harcaması grubunda sınıflandırılabilir. Bu durum ise sağlık hizmetlerinin, işgücünün üretkenliğini artırmaya yönelik birikim harcaması kategorisinde gösterildiği Tablo 1 kapsamındaki sınıflandırma ile uyumsuzluk göstermektedir. Ancak O’Connor (2001) tarafından da belirtildiği üzere harcama kalemlerinin tamamının sadece tek bir kategori bağlamında ele almak mümkün olunamamakta, bazı harcamalar devletin her iki işlevselliği bağlamında da ortaya çıkabilmektedir.

İkinci olarak da aile hekimliği uygulaması kapsamında aile sağlığı ve toplum sağlı̆̆1 merkezlerince yürütülen sağlık hizmetlerinin sağlıkta dönüşüm programı kapsamında birinci basamak sağlı hizmetlerine verilen önemin bir sonucu olarak merkezi yönetim bütçesi kapsamında bulunduğu söylenebilir. Birinci basamak sağlık hizmeti, T.C. Sağlık Bakanlığı tarafından sağlığın teşviki, koruyucu sağlık hizmetleri ile teşhis, tedavi ve rehabilitasyon hizmetlerinin bir arada verildiği, bireylerin hizmete kolayca ulaşabildikleri, düşük maliyetle etkin ve yaygın sağlık hizmeti sunumu şeklinde tanımlanmaktadır. Bununla birlikte, sağlıkta dönüşüm programı ile koruyucu sağlık hizmetleri vurgusunun ön plana çıkarıldığı birinci basamak sağlık hizmetleri aile hekimliği sistemi kapsamında uygulanır hale gelmiştir. Aile hekimliği uygulaması doğrudan aile sağlığı ile toplum sağlığı merkezleri ve aile hekimliği yetkisi verilmiş birinci basamak sağlık hizmeti veren üniversiteler, askeri birlikler, hastaneler, kurum ve işyerlerindeki kurum hekimleri aracılığıyla gerçekleştirilmektedir. Bu kapsamda T.C. Sağlık Bakanlığı tarafindan belirtildiği şekliyle "aile hekimliği uygulaması ile Aile Sağlığı Merkezlerinde aile hekimi ve aile sağlığı çalışanları tarafından, birinci basamak sağlık hizmetlerinden bireye yönelik koruyucu, tanı, tedavi ve rehabilite edici sağlık hizmetlerinin verilmekte; Toplum Sağlığ 1 Merkezleri ve bağl1 birimlerce, bölgesindeki topluma yönelik sağlıkla ilgili risk ve sorunları belirleyerek bunların düzeltilmesi ve/veya önlenmesi için çalışmalar yürütülmektedir”. Sağlık sistemine yönelik bu 
uygulama dahilinde merkezi yönetim bütçesinde kapsamında Toplum Sağlığı Merkezleri tarafından gerçekleştirilen sağlık harcamalarının yer alması hali hazırda beklenen bir durumken, aile sağlı̆̆ merkezlerinin yer alması ise bu kapsamdaki sağlık hizmetlerinden yararlanabilmek için genel sağlık sigortası kapsamında bulunma zorunluluğunun bulunmuyor olması ile açıklanabilir. Aile hekimliği sistemi genel sağlık sigortası kapsamından bağımsız olarak sağlık hizmetinden yararlanabilmenin önünü açarken, bu hizmetin finansmanı prim kazançları ya da cepten ödemeler ile sağlanmaktadır. Dolayısıyla genel sağlık sigortası kapsamında prim kazancı bulunanlar ile gelir testi sonucuna göre prim borçlarını ödeyenler aile hekimliği uygulamasından ilave bir ücret ödemeksizin yararlanabilmektedir. Bununla birlikte prime esas kazancı bulunmayan ya da prim borcunu ödemeyenler ise aile hekimliği uygulamasından yararlanabilmek için cepten ödeme yapmak zorunda kalmaktadır. Bu doğrultuda aile hekimliği sistemine yönelik bu harcamalar her ne kadar toplumsal refah dolayısıyla da toplumsal gider harcaması olarak görünse de, gerek aile sağlığı merkezleri ile bireysel gerekse toplum sağlığı merkezleri ile toplumsal ölçekte işgücünün üretkenliğini artırma amacına hizmet ettiği söylenebilir. Nitekim Sağlık Bakanlığı tarafindan birinci basamak sağl1k hizmetlerinin etkili bir şekilde verilebilmesi ile toplumun hastalık yükünün azaltılmasının yanı sıra ikinci ve üçüncü basamak tedavi kuruluşlarında da daha iyi ve kaliteli sağlık hizmeti ve sağlık eğitimi verilmesine imkan sağlanacağı ifade edilmektedir. Dolayısıyla da aile hekimliği sistemi ile toplumsal sağlığın ötesinde sağlık sisteminin diğer basamaklarındaki yığılmanın önlenmesi, hastalığın önlenmesine bağlı olarak ilave maliyetlerin ortaya çıkmasının engellenmesi şeklinde sağlığın firsat maliyetini temel alan bir düzenlemeye geçildiği söylenebilir. Nitekim birinci basamak sağlık hizmetleri, gerek hali hazırdaki çalışanlara yönelik bireysel, gerekse yedek işgücü deposu oluşumunun önünde olası engel oluşturabilecek toplumsal ölçekteki sağlık problemlerinin ortaya çıkmasına engel oluşturacak şekilde, özellikle de koruyucu sağlık hizmetleri ile işgücünün sürdürülebilirliğine imkan sunmaktadır. Buna bağlı olarak da söz konusu sağlık harcamaları, bütçe kategorizasyonu bağlamında Tablo 1 ile uyumlu olacak şekilde, devletin birikim işlevine yönelik toplumsal sermaye harcaması grubunda sınıflandırılabilir. 


\subsubsection{Sosyal güvenlik kurumu bütçesi kapsamında sağlık harcamaları}

Türkiye'de sağlık hizmetlerinin finansman kaynağını oluşturan Sosyal Güvenlik Kurumu kapsamındaki sağlık harcamaları ele alındığında ise, merkezi yönetim bütçesi kapsamında ortaya çıkan azalmayı açıklayacak şekilde artan bir trende sahip olduğu görülmektedir. Bu doğrultuda Türkiye'deki sağlık sisteminin yapısı bağlamında Sosyal Güvenlik Kurumu bütçesi kapsamında yer alan sağlık hizmetlerine yönelik değerlendirme yapabilmek amacıyla aşağıda yer alan tablo sunulmuştur.

Tablo 2

SGK Sağlık Harcamaları (Milyon TL)

\begin{tabular}{|c|c|c|c|c|c|c|c|c|c|}
\hline Sağlık Harcamaları & 2010 & 2011 & 2012 & 2013 & 2014 & 2015 & 2016 & 2017 & 2018 \\
\hline Tedavi & 18468 & 21848 & 29206 & 33508 & 36295 & 39557 & 45594 & 51260 & 59092 \\
\hline Devlet Hastanesi & 9584 & 11255 & 16746 & 19718 & 21585 & 23858 & 28704 & 31242 & 38077 \\
\hline Üniversite Hastanesi & 3558 & 4100 & 5152 & 5950 & 6516 & 7087 & 8133 & 10264 & 10743 \\
\hline Özel Hastane & 5327 & 6493 & 7244 & 7839 & 8194 & 8612 & 8757 & 9754 & 10272 \\
\hline İlaç & 13547 & 14144 & 14300 & 15590 & 17388 & 18895 & 21374 & 25166 & 30989 \\
\hline Reçete Hizmet Bedeli & 0 & 0 & 0 & 83 & 154 & 146 & 217 & 313 & 339 \\
\hline Diğer & 541 & 550 & 645 & 757 & 765 & 814 & 863 & 948 & 1146 \\
\hline $\begin{array}{l}\text { Diğer (Tibbi Malzeme, } \\
\text { Diş, Optik vb.) }\end{array}$ & 493 & 508 & 605 & 708 & 713 & 758 & 807 & 893 & 54 \\
\hline Yolluk Giderleri & 47 & 42 & 40 & 49 & 51 & 55 & 56 & 55 & 1092 \\
\hline Toplam & 32556 & 36542 & 44151 & 49938 & 54603 & 59411 & 68048 & 77687 & 91556 \\
\hline \multicolumn{10}{|c|}{ Kaynak. T.C. Sosyal Güvenlik Kurumu SGK İstatistik Yıllıkları kullanılarak hazırlanmıştır. } \\
\hline \multicolumn{10}{|c|}{ Sosyal Güvenlik Kurumu bütçesi kapsamında sağlık harcamalarına yönelik tedavi ve ilaç } \\
\hline \multirow{2}{*}{\multicolumn{10}{|c|}{$\begin{array}{l}\text { giderleri olmak üzere iki temel harcama kalemi bulunmaktadır. Tablo } 1 \text { kapsamında } \\
\text { değerlendirildiği gibi bu harcama kalemlerindeki yüksekliğin ve artışın temel sebebi, } 2010 \text { yılından }\end{array}$}} \\
\hline & & & & & & & & & \\
\hline \multicolumn{10}{|c|}{ beri kamu görevlilerinin, 2012 yılından itibaren ise yeşil kartlıların sağlık harcamalarının Sosyal } \\
\hline \multicolumn{10}{|c|}{$\begin{array}{l}\text { Güvenlik Kurumu bütçesine aktarılmasıdır. Bu artış } 2010 \text { yılı öncesine ait veriler dikkate } \\
\text { alındığında daha belirgin hale gelmekte olup, bu durum aşağıda yer alan şekilde açıklıkla }\end{array}$} \\
\hline
\end{tabular}




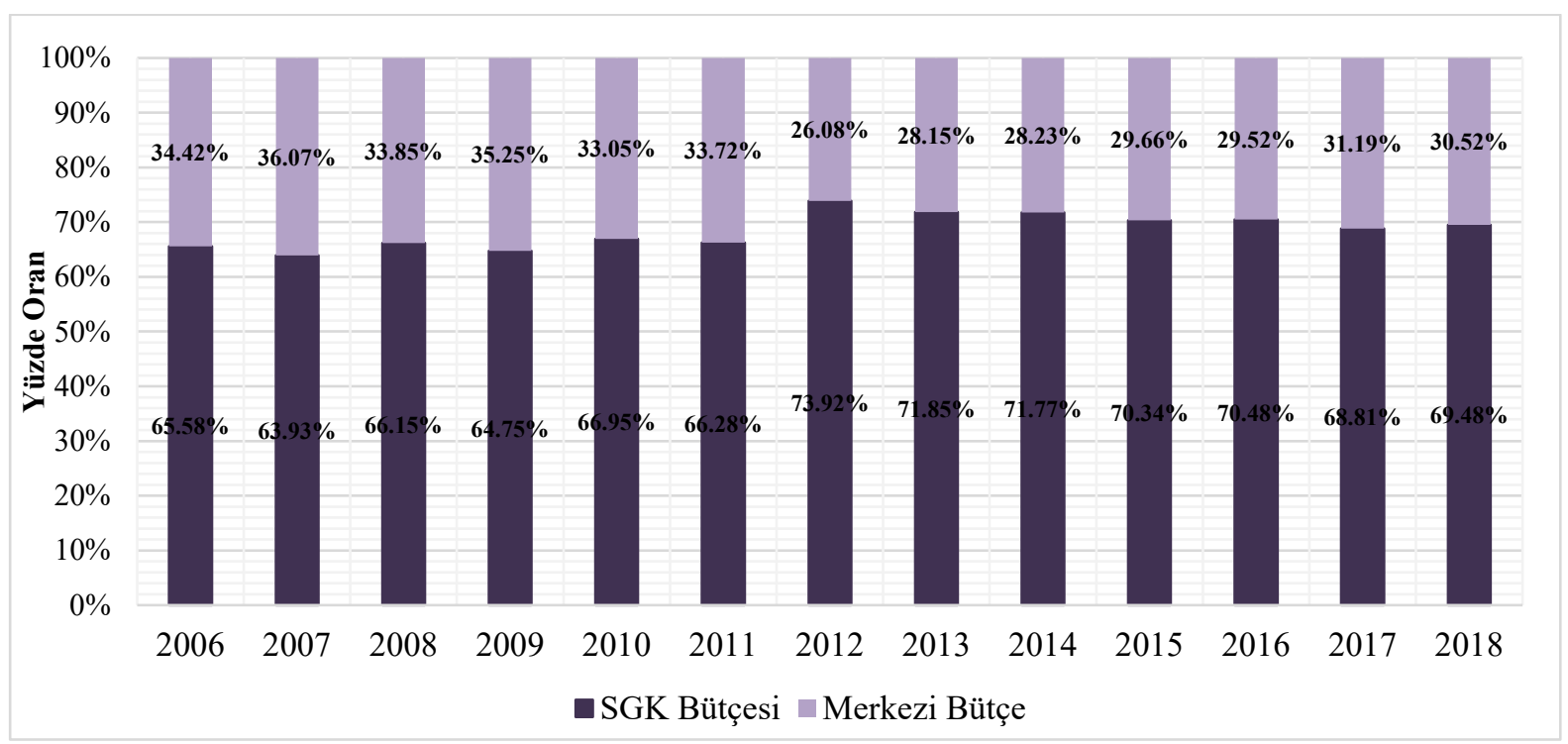

Şekil 2. Genel Bütçe Kapsamında Sağlık Harcamalarının Oransal Dağılımı (2006-2018).T.C. Hazine ve Maliye Bakanlığı Genel Yönetim Bütçe İstatistikleri kullanılarak hesaplanmıştır.

SGK bütçesi kapsamındaki sağlık harcamalarında ortaya çıkan belirgin artış, Şekil 1 kapsamında değerlendirilen merkezi yönetim bütçesi kapsamındaki sağlık harcamalarının da seyri dikkate alındığında sağlıkta dönüşüm programı ile sağlık hizmetlerinin SGK şemsiyesi altında toplanması halini destekler niteliktedir. Özellikle de kamu görevlileri ile yeşil kartlılara ait sağlık harcamalarının SGK bütçesine aktarılması, 2010 ve 2012 yıllarında merkezi yönetim bütçesinde belirgin düşüşe (Şekil 1), SGK bütçesinde ise artış oranının artmasına neden olmuştur. Bununla birlikte ortaya çıkan bu durum, SGK bütçesindeki sağlık harcamalarının ana kalemi niteliğindeki tedavi giderlerinin sağlık kurumu bazındaki dağılımı incelendiğinde sağlıkta dönüşüm programının etkisi daha da belirgin hale gelmektedir. Bu kapsamda SGK bütçesinin ağırlıklı harcama kalemi olan tedavi giderlerinin sağlık kurumları bazındaki dağılımı aşağıdaki şekil aracılığıyla özetlenmektedir. 


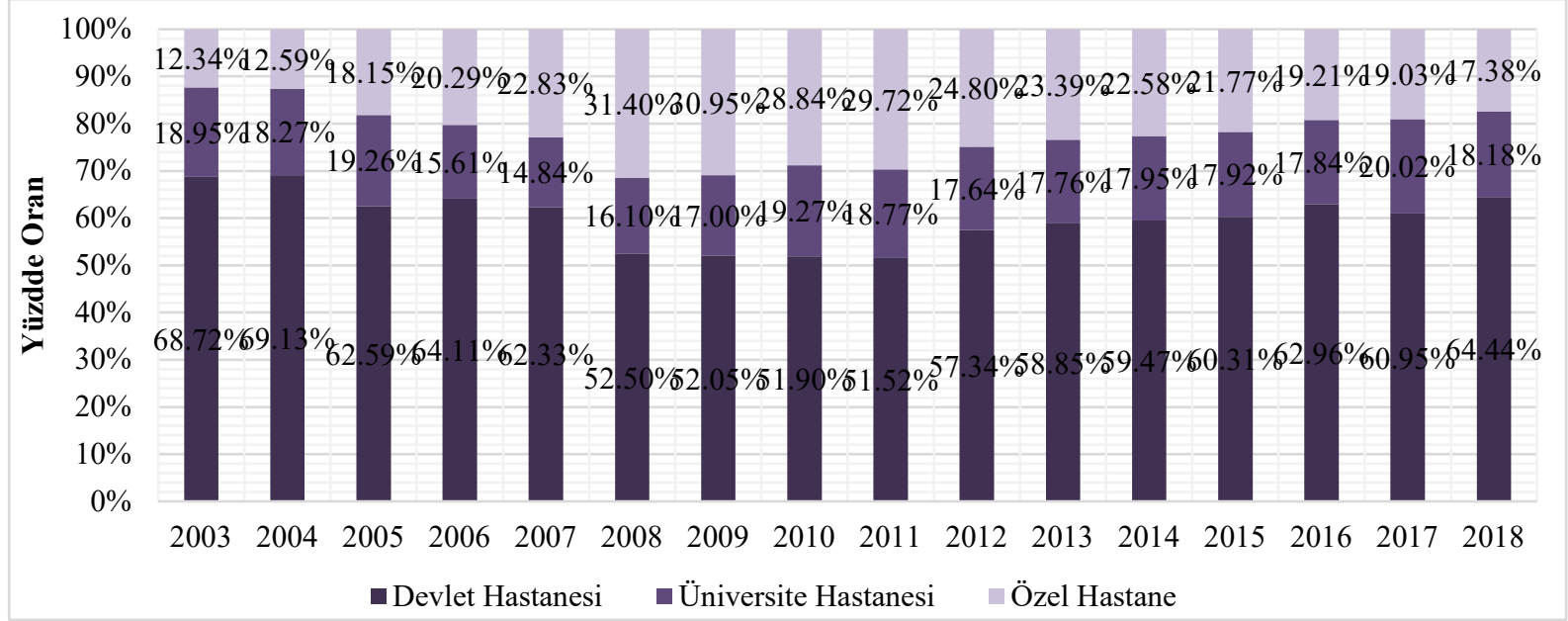

Şekil 3. SGK Tedavi Harcamalarının Sağlık Kurumları Bazında Dağılımı (2003-2018). T.C.

Sosyal Güvenlik Kurumu SGK İstatistik Yı1lıkları kullanılarak hazırlanmıştır.

Şekilde görüldüğü gibi SGK bütçesi kapsamındaki sağlık harcamalarının temel kalemini oluşturan tedavi giderlerinin önemli bir bölümünü ikinci ve üçüncü basamak sağlık kurumu olan devlet hastaneleri oluşturmaktadır. SGK bütçesi kapsamındaki ikinci ve üçüncü basamak sağlık kurumu niteliğindeki özel hastaneler ile üçüncü basamak sağlık kurumu niteliğindeki üniversite hastanelerinin payı ise göreli olarak düşük olmakla birlikte azımsanamayacak düzeyde olduğu söylenebilir. Bununla birlikte yıllar itibariyle sağlık kurumlarının oransal dağılımına bakıldığında, üniversite hastanelerinin payında önemli bir değişim olmadığı görülmektedir. Diğer taraftan yıllar itibariyle devlet hastaneleri ile özel hastanelerin oransal dağılımında önemli ölçüde değişiklik ortaya çıkmıştır. Genel Sağlık Sigortası uygulamasının yürürlüğe girdiği 2008 yılına kadar özel hastanelerin payı sürekli artarken, devlet hastanelerin payı sürekli azalmıştır. Genel Sağlık Sigortasının yürürlüğe girmesiyle ise özel hastanelerin payı sürekli azalmış, devlet hastanelerinin payı sürekli artmıştır. 2003 yılından itibaren incelenen bu durumun birbiriyle bağlantılı iki temel sebebi bulunduğu söylenebilir. İlk olarak sağlıkta dönüşüm programı kapsamında özel hastanelerinin kapılarının herkese açılması bir etken olarak kabul edilebilir. Bu uygulama ile özel hastanelerden mevcut sosyal güvence kapsamında herkes yararlanabilir hale gelmiştir (Akdağ, 2012). Buna bağlı olarak da SGK bütçesi kapsamında özel hastanelerin payı oransal olarak artmıştır. İkinci olarak ise Türkiye'de özel sağlık sigortacılığı sisteminin gelişimi diğer bir etken faktör olarak kabul edilebilir. Özel sağlık sigortası sisteminin gelişiminin SGK bütçesi üzerindeki etkisi ise, özel sağlık sigortasının mevcut sağlık sigortasının tamamlayıcısı olarak kullanılması ile 
ortaya çıkmıştır. Bu uygulama ile özel sağlık sigortasına sahip olanların, özel hastanelerdeki tedavi giderlerinin bir kısmı mevcut sosyal sağlık sigortası kapsamında, kalan bir kısmı da özel sağlık sigortası kapsamında karşılanır hale gelmiştir. Bu duruma bağlı olarak da özel sağlık sigortası sahipleri tarafından devlet ya da üniversite hastanelerinin alternatifi olarak özel hastaneler cazip hale gelmiştir. Bununla birlikte özel sağlık sigortasına nüfusun sadece belirli bir kısmı sahiptir. Bu durum yapılan bilimsel çalışmalar (Tarım \& Güdük, 2019) ile de ortaya koyulduğu gibi özel sağlık sigortası ile gelir düzeyi arasında güçlü bir ilişkinin bulunmasından kaynaklanmaktadır. Buna bağlı olarak da 2008 öncesi ve sonrasında SGK bütçesi kapsamında özel hastanelerinin payında ortaya çıkan göreli farklılık, özellikle de yeşil kartlıların SGK bütçesine aktarıldığı 2012 yılından itibaren daha da belirgin niteliktedir. Bu durum da düşük gelir grubundaki yeşil kartlıların, tamamlayıcı sağlık sigortası olarak özel sağlık sigortasından yararlanamamaları dolayısıyla da özel hastaneler yerine alternatif sağlık kurumlarını tercih etmelerinden kaynaklanmaktadır.

SGK bütçesi kapsamındaki sağlık harcamaları, O’Connor'ın mali kriz kuramı kapsamında gerçekleştirdiği bütçe kategorizasyonundan hareketle ele alındığında ise merkezi yönetim bütçesi kapsamındaki sağlık harcamalarından farklı bir durum ortaya çıkmaktadır. Bu farklılık, merkezi yönetim bütçesi kapsamındaki sağlık harcamalarında devletin meşruiyet ve birikim şeklindeki her iki işlevselliğinin de ortaya çıkmasının aksine, SGK bütçesi kapsamındaki sağlık harcamalarının doğrudan doğruya devletin birikim işlevine karşılık gelmesinden oluşmaktadır. O’Connor tarafından, sağlık sigortası, toplumsal sermaye harcamalarının alt kategorisinde yer alan toplumsal tüketim harcaması olarak kabul edilmektedir. O’Connor'a (2001) göre toplumsal tüketim harcamaları iki grupta ele alınmaktadır. İlk grupta banliyölerin kalkındırılmasına yönelik projeler (yol, ilk ve orta seviye okul, eğlence tesisleri, ipotekli konut destekleri ve garantileri), şehirlerin yenilenmesine yönelik projeler ve çocuk bakımı, hastane ve tıp merkezleri ile ilişkili projeler yer almaktadır. İkinci grupta ise işçi sigortası, yaşlılık sigortası, işsizlik sigortası ve sağlık sigortası bulunmaktadir.

Toplumsal tüketim harcamalarının ilk grubunda yer alan harcamalar, modern kapitalist sistemin gelişiminin toplumsal örgütlenme yapısında ortaya çıkardığg dönüşüm temelinde ele alınarak açıklanmıştır. Modern kapitalist sistem öncesi su kaynaklarının, atık bertaraf sistemlerinin, ulaştırma, haberleşme, barınma, dinlenme ve kültürel faaliyetlerin temini, kırsal kesimde ve çiftlikte yaşayan ailelerin kendileri tarafından temin edilmektedir. Şehirlerde de aile sistemleri, 
etnik örgütlenmeler, gruplaşma genişletilerek ve hayırseverlik ile hastalığa, yaşlılığa, işsizliğe ve diğer felaket olaylarına karşı bir tür sosyal sigorta oluşturulmuştur. Aksine modern kapitalist sistem ise, endüstriyel, ticari, taşımacılık, konut ve dinlenme alanlarında artan bağımlılıklar nedeniyle, sosyal tüketim harcamalarının artmasını gerektirmiştir. Nüfusun genelinde artan proleterleşme, işlemlerin, iş bölümünün ve yaygın haldeki banliyöleşmenin yoğun şekilde spesifik bir hal alması ile tipik işçi sınıfı ailesinin kendi yaşam olanaklarını temin etmesi giderek daha zor hale gelmiştir. Ayrıca üretim araçlarının özel mülkiyeti ve genel toplumsal planlamanın olmayışı, tesislerin ve ekonomik atıkların ciddi şekilde artması, toplumsal tüketim harcamalarını zahmetli hale getirmiştir. Buna göre modern kapitalist toplumlarda özellikle tekelci piyasadaki işçiler için, toplumsal ürünün artan kısmı toplumsal tüketim harcamalarına ayrılmak zorunda kalmaktadır.

Toplumsal tüketim harcamalarının ikinci grubunda yer alan harcamalar, işçilere ve ailelerine yönelik iş kazaları, hastalık, yaşlılık, emeklilik, ölüm, işsizlik ve iş ile ilgili olmayan sağlıksızlık hallerine karşı sosyal güvenlik şeklinde sağlanan transfer ödemeleridir. Sosyal güvenlik programları büyük ölçüde 1930'lar ve 1940'larda demiryolu çalışanlarına yönelik oluşturulan emeklilik sistemi, yaşlılık sigortası, işsizlik sigortası, hayat sigortası ve devlet çalışanlarına yönelik çeşitli emeklilik planları şeklindedir. Ancak zamanla yapılan düzenlemeler ve sosyal sigorta sistemine dahil olan aktif nüfusun emekli olmaya başlaması, ulusal sağlık sigortasının da sosyal güvenlik kapsamına dahil edilmesiyle sosyal güvenlik dolayısıyla da toplumsal tüketim harcamalarında önemli bir artış gerçekleşmişstir. O'connor tarafindan bu artış sosyal güvenlik sisteminin temel amacının yanlış anlaşılmasından kaynaklandığı şeklinde açıklanmaktadır. İş kazası sigortası, yaşlılık sigortası ve işsizlik yardımından yararlanma hakkı, sadece refah seviyesi yüksek olan çalışanlar için söz konusudur. Diğer bir ifadeyle kapitalist ekonomik gelişmeye eşlik eden teknolojik işsizlik, konjonktürel işsizlik ve diğer işsizlik türlerinin doğrudan etkisi ile sosyal güvenlik sistemi yaygınlaşmıştır. Bu durum ise sosyal güvenlik yardımlarının toplumsal tüketim harcaması olarak değil, toplumsal gider harcaması olarak kabul edilmesi gerektiğine neden olmuştur. Halbuki sosyal güvenliğin işsizleri ve emeklileri koruyarak toplumsal ve politik istikrara sağladığı katkıya rağmen, temel amacı istihdam edilen işgücüne (özellikle tekelci piyasadaki işgücü) yönelik ekonomik güvence sağlamak ve bu sayede ahlaki yükseliş ve disiplinin pekiştirilmesini sağlamaktır. Bu durum ise sermaye birikimi ve üretimin büyümesi için elzem nitelikte olan yönetim ile emek arasındaki ilişkinin uyumlu bir şekilde yürütülmesine katkı sağlayacaktır. Sosyal güvenliğin temel niyeti ve etkisi üretkenliğin, üretimin 
ve kârın genişletilmesidir. Bu açıdan bakıldığında sosyal güvenlik, esas olarak çalışanlar için bir güvence değil, aksine kapitalistler ve şirketler için sigorta niteliğindedir (O'Connor, 2001, 138).

$\mathrm{Bu}$ çerçevede sağlıkta dönüşüm programı kapsamında sağlı̆̆ın sosyal güvenlik şemsiyesi altında toplanması ile Türkiye'deki sağlık harcamalarının doğrudan doğruya sosyal tüketim harcamas1 niteliğine dönüştürüldüğü söylenebilir. Bununla birlikte O'Connor tarafından da belirtildiği gibi sosyal güvenlik sisteminin amacının yanlış anlaşılmış olması, SGK bütçesi kapsamında yeşil kartlıların yer alması, bu kapsamdaki sağlık harcamalarının toplumsal gider harcaması olarak görünmesine neden olabilmektedir. Ancak SGK bütçesi kapsamında sağlık güvencesine hak kazanabilmenin temel koşulunun prime esas kazanç sahipliğine bağlanıyor olması, sosyal güvenlik şemsiyesi altındaki sağlık sisteminin esas itibariyle üretkenlik lehine işgücünün üretkenliğini artırma amacını desteklediği söylenebilir.

\section{Sonuç}

Kamu harcamaları içinde sağılı harcamaları oranının gösterdiği artış, devlet tarafından sağlığa verilen önemin bir göstergesi olarak kabul edilmektedir. Bununla birlikte kapitalist üretim biçimi dahilinde devletin sahip olduğu rol ve dolayısıyla kamu harcamaları üretim ilişkileri dahilinde belirlenmektedir. $\mathrm{Bu}$ durum da kamu harcaması niteliğindeki sağlık harcamalarının insani bir hak olarak sağlığa verilen önemin göstergesi olma niteliğini engellemektedir. Nitekim kapitalist ilişki ağında sağlı̆̆ın içeriği temel insani hak olmanın ötesinde emeğin yeniden üretimini temin eden bir araç haline gelmektedir. Buna bağlı olarak da işgücünün sürdürülebilirliği, dolayısıyla da sermaye birikiminin temel bileșenlerinden biri olarak sağlık harcamalarının finansmanı sorunsalı ortaya çıkmaktadır.

Kamu harcamalarını toplumsal gider ve toplumsal sermaye harcamaları olarak sınıflandıran O'Connor tarafından sağlık harcamaları diğer bütün harcama kalemleri için olduğu gibi her iki kategoride de yer alabilmektedir. Ancak O'Connor tarafindan yapılan kategorizasyonda temel belirleyici, kamu harcama kalemlerinin fonksiyonel dağılımının ötesinde bu harcamaların amacıdır. Bununla birlikte yukarıda da belirtildiği gibi kapitalist üretim ilişkilerinde devletin rolüne bağlı olarak kamu harcamalarının amaçları da sistemin sürdürülebilirliğine uygun olarak belirlenmektedir. Sağlık harcamalarının da her ne kadar toplumsal refah sağlama amacı doğrultusunda toplumsal gider harcaması niteliği bulunsa da esas olarak toplumsal sermaye harcaması niteliğinde olduğu düşünülmektedir. 
Türkiye'deki sağlık harcamaları merkezi yönetim bütçesi ve SGK bütçesi olmak üzere iki farklı kategoride olacak şekilde genel yönetim bütçesi kapsamında yer almaktadır. Genel yönetim bütçesi kapsamındaki bu ayrım, O’Connor'ın mali kriz kuramı kapsamında yer alan bütçe kategorizasyonundan hareketle değerlendirildiğinde de devam etmektedir. Buna göre merkezi yönetim bütçesi kapsamındaki sağlık harcamaları ağırlıklı olarak toplumsal gider harcaması niteliğindeyken, SGK bütçesi kapsamındakiler doğrudan doğruya toplumsal sermaye harcaması niteliğindedir. Ayrıca toplumsal sermaye harcaması içinde yapılan toplumsal yatırım ve toplumsal tüketim şeklindeki alt kategorizasyona göre de sosyal güvenlik harcamaları toplumsal tüketim harcaması kategorisinde yer almaktadır. Genel yönetim bütçesi kapsamındaki sağlık harcamalarının da önemli kısmının SGK bütçesi kapsamında yer aldığı düşünüldüğünde, sağlık harcamalarının önemli bir kısmının O’Connor'ın toplumsal sermaye harcamasının alt kategorisi niteliğindeki toplumsal tüketim harcaması niteliğinde olduğu söylenebilir.

Bu çerçevede Türkiye'deki sağlık harcamalarının sağlık sisteminin geçirdiği dönüşüme bağlı olarak merkezi yönetim bütçesi yerine sosyal güvenlik sistemi içinde yer almasının üretim biçiminin bir sonucu olduğu söylenebilir. Buna bağlı olarak da sağlık harcamalarının finansmanı esas itibariyle gelire esas kazançlar ile sağlanmakta, sağlık hakkı sosyal ve ekonomik bir hakka dönüşmektedir. Bu durumun meşruiyeti ise gerek yasal bağlamda gerekse genel geçer söylem ile mali disiplin kavramı ile sağlanmaktadır. Nihayetinde O'Connor'ın mali kriz kuramı kapsamında yer alan bütçe kategorizasyonundan hareketle yapılan değerlendirme sonucunda, Türkiye'deki sağlık harcamalarının, dolayısıyla da sağlık sisteminin mevcut üretim biçimi içindeki rolüne uygun şekillendirildiği söylenebilir. 


\section{Kaynakça}

Akdağ, R. (2012). Türkiye Sağlikta dönüşüm programı değerlendirme raporu (2003-2011), Ankara: $\quad$ T.C. Sağlık Bakanlığı. Alınan yer https://sbu.saglik.gov.tr/Ekutuphane/kitaplar/SDPturk.pdf

Arslan, İ., Eren, M. V. \& Kaynak, S. (2016). Sağlık ile kalkınma arasındaki ilişkinin asimetrik nedensellik analizi. Dokuz Eylül Üniversitesi İktisadi ve İdari Bilimler Fakültesi Dergisi, 31(2), 287-310. doi: 10.24988/deuiibf.2016312535

Bıçakcı, S. C. (2017). Bütçe kategorizasyonu gölgesinde devletin işlevleri: bir kategorizasyon denemesi. Ankara Üniversitesi SBF Dergisi, 72(4), 1081-1106. doi: 10.1501/SBFder_0000002478

Çalışkan, Z. (2009). OECD ülkerinde sağlık harcamaları: panel veri analizi. Erciyes Üniversitesi İktisadi ve İdari Bilimler Fakültesi Dergisi, (34), 117-137.

Çavmak, Ş. \& Çavmak, D. (2017). Türkiye'de Sağlık hizmetlerinin tarihsel gelişimi ve sağlıkta dönüşüm programı. Sağllk Yönetimi Dergisi, 1(1), 48-57.

Çelik, A. (2020). G20 Ülkelerinde sağlı harcamalarının ekonomik büyüme üzerindeki etkisinin analizi. Yönetim ve Ekonomi, 27(1), 1-20. doi: 10.18657/yonveek.594695

Engels, F. (2019). Ailenin, özel mülkiyetin ve devletin kökeni. Yordam Kitap.

Erdoğdu, S. (2013). Sosyal politikada değişim ve sosyal güvenlik reformu. İçinde İ. Uzgel, \& B. Duru (Ed.), AKP Kitabı: Bir Dönüşümün Bilançosu (ss. 660-686). Ankara: Phoenix Yayınevi.

Gürkan, C. \& Karahanoğulları, Y. (2013). Vergi devletine kuramsal yaklaşımlar. Maliye Dergisi, (165), 1-26.

Konca, M., Gözlü, M. \& Çakmak, C. (2019). G-20 ülkelerinin sağlık harcamaları yönünden etkinliğinin değerlendirilmesi. Verimlilik Dergisi, (2), 119-141.

O'Connor, J. (2001). The Fiscal Crisis of the State. New York: St. Martin's Press.

Selim, S., Uysal, D., \& Eryiğit, P. (2014). Türkiye'de sağlık harcamalarının ekonomik büyüme üzerindeki etkisinin ekonometrik analizi. Niğde Üniversitesi İktisadi ve İdari Bilimler Fakültesi Dergisi, 7(3), 13-24.

Şaşmaz, M. Ü., Odabaş, H., \& Yayla, Y. E. (2019). OECD ülkelerinde sağlık harcamaları ile kalkınma arasındaki ilişki: panel veri analizi. Yönetim ve Ekonomi, 26(3), 851-866. doi: 10.18657/yonveek.544425

T.C. Sağlık Bakanlığı Halk Sağlığı Genel Müdürlüğü Aile Hekimliği Dairesi Başkanlığı (2019). Alınan Yer https:/hsgm.saglik.gov.tr/tr/ailehekimligi/birinci-basamaksa\%C $4 \% 9 F 1 \% C 4 \% B 1 k$-hizmetleri.html 
T.C. Hazine ve Maliye Bakanlığı (2020). Genel Yönetim Mali İstatistikleri. Alınan yer https://muhasebat.hmb.gov.tr/genel-yonetim-mali-istatistikleri

T.C. Sosyal Güvenlik Kurumu (2020). SGK İstatistik Yıllıklart. Alınan yer http://www.sgk.gov.tr/wps/portal/sgk/tr/kurumsal/istatistik/sgk_istatistik_yilliklari

Tarım, M. \& Güdük, Ö. (2019). Türkiye'de bireylerin özel sağlık sigortası tercihini etkileyen nedenler ve bilgi düzeyleri. Sağlık Akademisyenleri Dergisi, 6(3), 196-200.

Tıraşoğlu, M., \& Yıldırım, B. (2012). Yapısal kırılma durumunda sağlık harcamaları ve ekonomik büyüme ilişkisi: Türkiye üzerine bir uygulama. Electronic Journal of Vocational Colleges. 111-117. doi:10.1501/OTAM_0000000515 